\title{
The Impact of Gender and Academic Degrees on the Performance of Transversal Competencies in Higher Education Students
}

\author{
Gema Santiago Gómez¹, Oscar García López², Ignacio Diez Vega³ \\ Sara Redondo Duarte ${ }^{4} \&$ Silvia Lavandera Ponce ${ }^{5}$ \\ ${ }^{1}$ Dean's Office, Faculty of Biomedical Sciences and Health, Universidad Europea de Madrid, Madrid, Spain \\ 2 Department of Psychology, Universidad Europea de Madrid, Madrid, Spain \\ ${ }^{3}$ Department of Nursing and Physiotherapy, Universidad de León, León, Spain \\ ${ }^{4}$ Deputy Dean's Office for Institutional Relations and University Life, Universidad Europea de Madrid, Madrid, \\ Spain \\ ${ }^{5}$ Center for Excellence in Teaching and Learning, Universidad de Ingenieríay Tecnología, Lima, Peru. \\ Correspondence: Santiago Gómez, Gema, Faculty of Biomedical Sciences and Health, Universidad Europea de \\ Madrid, Madrid, Spain.
}

Received: October 22, 2021

Accepted: January 27, 2022

Online Published: January 31, 2022

doi:10.5430/ijhe.v11n3p148

URL: https://doi.org/10.5430/ijhe.v11n3p148

\begin{abstract}
There is some consensus among academics and employers that transversal competencies are one of the key aspects in training people to adapt to the demands of today's world. Universities make a great effort in the design of training programs, in preparing their teachers in training methodologies and in the evaluation systems to guarantee that their graduates acquire an adequate level of these skills. However, there are few studies that address the impact of gender and academic degrees on the performance of transversal competencies.

This study aims to assess whether gender and degree have any impact on the level of transversal competencies obtained at the end of their higher education studies. To this end, we have evaluated 1,614 final year students from 11 higher education centers using a standardized questionnaire on the competencies of Communication, Leadership, Teamwork, Adaptation to change, Initiative, Problem solving, Decision-making, Planning and Organization. We have carried out a Multivariate Variance Analysis to analyze the effect of gender, degree and the interaction between both factors on the students' competence profile. The results show that men perform better in Leadership, Initiative and Decision-making, whereas women score better in Planning and Teamwork skills. Students of Social Sciences degrees have a poorer performance in the competencies than students of Health Sciences and Technical Education. In Planning, women perform better, regardless of the degree, compared to men.
\end{abstract}

Keywords: higher education, transversal skills, standardized questionnaire, assessment of skills, gender differences, academic degrees

\section{Introduction}

Since the European Higher Education Area introduced competence development as one of its main training objectives (European Higher Education Area, 1999), universities have implemented the competence model in their degrees (Casanova, 2016). This model has been carried out from the curricular designs, working on the

development and evaluation of competencies (Barrientos, Silva and Antúnez, 2016), in the activities that are carried out in the day to day of the classroom, and even incorporating complementary ad hoc training programs (Ferrari, Santiago, Redondo, and Sánchez, 2015).

In this way, the skills-based model has positioned itself as one of the main means of providing students with training geared to the professional world, to the needs of society (Morgado, Peñalvo, Ortuño, and Hidalgo, 2015) and to adapting to the demands of today's world (Rodríguez, 2004; Fragoso-Luzuriaga, 2015).

Transversal competencies are considered a key aspect for the performance of a large number of jobs in recent graduates, being transferable in different careers and providing greater employability (Ferrari, Santiago, Redondo, and Sánchez (2015). Several authors (Castellanos, Sánchez, and Calderero, 2017; Mendoza, del Barco, Felipe, Polo, 
2016) have described social interaction skills as key to perform successfully in the professional world. On the other hand, employers demand a high level of graduates in competitive matters (Tobón, 2006), organizational achievement (Alles, 2006), quick integration into teams, organizational culture and job performance, hoping that they will bring added value to the organization (Harvey, Moon and Geall, (1997), extracted from Diaz, 2005).

However, various reports highlight the insufficient performance of graduates in different personal and interpersonal skills, as indicated by the Barometer of Employability and Employment of University Students in Spain (2016), the everis foundation's University-Company Ranking (2015), The Innovation for Employment Observatory (2014), The Report on Professional Competencies in Pre-University and University Studies in Latin America (2013), Van-der Hofstadt Roman y Gras (2013) and The report of the Institute of Education Sciences of the University of Zaragoza, (ICE 2008) and the Career after Higher Education survey: a European Research Study (Hernandez, Del Peso and Leguey, 2009).

Despite the great importance of competencies within the academic world, there is no consensus between the different systems of evaluation of these competencies which would allow a coherent and shared model to be established (Santiago, García and Redondo, 2018). Even establishing a definition of competencies is not without controversy, since there is conceptual and terminological confusion and imprecision (Corominas, 2005), which makes it difficult to reach a clear consensus on their main aspects.

In short, the incorporation of university graduates into the world of work is not without its difficulties, and universities must respond to society's demands in terms of developing skills. Despite the interest in the subject, there are aspects that have not been studied in current research: Are all our students competently equal when they finish their studies? Do men and women achieve the same level of skills at the end of their training? Does the degree have an influence on the development of students' skills? These questions must be answered so that higher education institutions can prepare their courses, activities and teaching methods more efficiently.

The present study is based on a descriptive design by means of a survey, of a transversal type, since the measurement was made at a single moment in time (Montero and León 2002). The sample was causal in students in their final year of higher education in 11 Spanish educational institutions, both public and private. The STROBE recommendations (Von Elm, Altman, Egger, Pocock, Gøtzsche, and Vandenbroucke, 2008) have been followed for the writing of the article.

\subsection{Research Questions}

Is gender related to the way in which young people develop their competence? Is the study profile associated with the performance of competence of the student after completion of the training pathway? Are there differences in transversal competence between men and women according to the degree? To answer these questions, the research objectives of this study are:

- Compare the differences in the performance of skills between men and women.

- Compare the results between the different degrees.

- Compare the results between men and women in the different degrees.

\section{Research Method}

\subsection{The Sample}

The sample was made up of 1,614 students belonging to 78 different degrees taught in 11 public and private higher education centers. $47.3 \%$ were men and $52.7 \%$ women, with an average age of 25.2 years ( $\mathrm{SD}=6.6), 92 \%$ of whom were under or equal to 35 years of age. According to the areas of studies, $36.9 \%$ of the participants studied Social Science, $47 \%$ studied Health Science and $16.1 \%$ studied Technical degrees. No international framework has been found to establish a standardized classification of areas of education, so the International Standard Classification of Education (UNESCO 1997) has been taken as a reference. The sub-areas included in each subject area were:

- Social Sciences: Legal, Communication, Education, International Relations, Business, Finance, Marketing and Sociology.

- Health Sciences: Pharmacology, Biotechnology, Optics, Podiatry, Medicine, Dentistry, Nursing and Physical Education

- Technical degrees: Architecture, Design and Engineering

The evaluation was carried out using the standardized COMPE-UEM questionnaire from TEA Editions1. It is an adaptation for university students of the COMPETEA test (2015), recommended by the General Council of Official 
Colleges of Psychologists for the evaluation of competencies in work contexts (2013). This self-report test consists of 80 items in which the student must answer the statements presented to him/her according to the frequency or agreement with which certain behaviors and statements occur in him/her. The scale used is Likert type, with values between 1 and 5, where 1 disagrees or not at all and 5 agrees or very frequently. The estimated time of completion is 30 minutes and the test has a total reliability of $\alpha=0.74$. The transversal competencies evaluated were:

- Communication: adapt the speech to the language of the interlocutor to transmit the information in a clearer, more precise and more convincing way.

- Leadership: having the charisma of a leader to influence others or represent the actions of an individual or group.

- Teamwork: participate, collaborate and contribute to the decisions and initiatives of the group to carry out a collective task.

- Adaptation to change: a person who is confident, who faces and adapts skillfully to the social situations that surround them.

- Initiative: to take action outside the strictly established functions and to be more concerned with improving the quality, profitability or effectiveness of the results of an activity than others.

- Problem solving: take a resolution and act on it by determining a plan of action and taking the necessary risks.

- Decision-making: assumes responsibility for problems, takes into account the benefits for the company and the risks on the consequences of a decision.

- Planning and organization: coordinate, separate and prioritize different tasks to meet the work plans and strategic objectives of the company.

In relation to the procedure, the tests were carried out in person during the students' class time. Before starting the evaluations, the evaluators reported on the voluntary nature of the participation and the treatment of the information in an aggregate way. Once the students had accepted to take the test, the evaluator gave the corresponding instructions for the correct performance and registration of the test, the estimated time for its completion, and they were assisted in resolving any doubts about the procedure or questionnaire.

\subsection{Measurement of Variables and Analysis Strategy}

The statistical analysis was done with SPSS v.21 for Windows. The mean and standard deviation were used as descriptive statistics to report the results obtained by the participants.

An Analysis of Multivariate Variance (MANOVA) was used to analyze the effect of gender, degree and the interaction between both factors (gender by degree) on the competence profile of students. For those factors that presented a significant effect, a post-hoc analysis was carried out with the Bonferroni test, to determine between which groups there were differences. The significance level was set at $\mathrm{p}=0.05$ for all analyses.

To interpret the size of the differences found, partial square stage was used $(\eta 2 p)$. Large $(\eta 2 p>0.14)$, moderate $(\eta 2 p>0.06)$ and small $(\eta 2 p<0.01)$ effect sizes were considered (Castro and Martini, 2014).

\section{Results}

The multivariate analysis revealed significant effects of gender $(\lambda(8.16)=0.94 ; p<0.001 ; \eta 2 p=0.065)$, degree $(\lambda$ $(16.32)=0.93 ; p<0.001 ; \eta 2 p=0.037)$ and gender interaction by degree $(\lambda(16.32)=0.97 ; p<0.001 ; \eta 2 p=0.013)$ on the competence development of students. Gender explained $6.5 \%$ of the competence variance, the degree $3.7 \%$ and the interaction degree $\mathrm{x}$ gender $1.3 \%$, which means moderate and small effect sizes respectively.

Table 1 presents means, standard deviations and analysis of variance by gender. The competencies Leadership, Teamwork, Initiative, Decision-making and Planning were statistically different between men and women ( $<<0.05$ ), although the differences between the two genders were small $(\eta 2 \mathrm{p}<0.01)$. Men scored significantly higher on Leadership, Initiative and Decision-making, whereas women scored better on Planning and Teamwork competencies. 
Table 1. Descriptive statistics and analysis of variance by gender

\begin{tabular}{lllll}
\hline & $\begin{array}{l}\text { Male } \\
(\mathrm{n}=764)\end{array}$ & $\begin{array}{l}\text { Female } \\
(\mathrm{n}=850)\end{array}$ & $\mathrm{p}$ & $\eta 2 \mathrm{p}$ \\
\hline Communication & $21,28 \pm 3,2$ & $21,46 \pm 3,1$ & 0,057 & 0,002 \\
Leadership & $\mathbf{2 3 , 2 2 \pm \mathbf { 3 , 6 }}$ & $22,11 \pm 4$ & $\mathbf{0 , 0 0 2}$ & 0,006 \\
Teamwork & $21,61 \pm 3,6$ & $\mathbf{2 2 , 1 1} \pm \mathbf{3 , 4}$ & $\mathbf{0 , 0 0 1}$ & 0,007 \\
Adaptation & $16,81 \pm 3,8$ & $\mathbf{1 6 , 2 5} \pm \mathbf{4 , 6}$ & $\mathbf{0 , 3 5 5}$ & 0,001 \\
Initiative & $29,39 \pm 3,3$ & $\mathbf{2 8 , 4 8} \pm \mathbf{3 , 4}$ & $\mathbf{0 , 0 0 1}$ & 0,007 \\
Problem solving & $29,28 \pm 4,2$ & $\mathbf{2 8 , 5 2} \pm \mathbf{4 , 2}$ & $\mathbf{0 , 1 1}$ & 0,002 \\
Decision-making & $21,36 \pm 3$ & $\mathbf{2 0 , 7 1} \pm \mathbf{2 , 9}$ & $\mathbf{0 , 0 0 4}$ & 0,005 \\
Planning & $22,43 \pm 3,6$ & $\mathbf{2 3 , 6 3} \pm \mathbf{3 , 4}$ & $\mathbf{0 , 0 0 1}$ & 0,028
\end{tabular}

Abbreviations. p: p-value (in bold significant differences); $\eta 2 p$ : partial eta squared.

Table 2 shows means, standard deviations and analysis of variance by degree. All competencies presented statistical differences $(p<0.05)$, although these were again small $(\eta 2 p<0.01)$. Social Science students scored lower than other degrees in all the competencies, except in Adaptation. Students in Technical Education were perceived as more competent than Social Science students in Teamwork, Adaptation, Planning, Leadership, Problem solving, Communication and Decision-making. In addition, they also scored higher on the Adaptive competence than the Health Science students. The Health Sciences students scored higher than the Social Sciences students in the competencies of Teamwork, Communication, Problem solving, Planning, Leadership and Decision-making. Finally, the Social Sciences students scored higher than the Health Sciences students in the Adaptation competence.

Table 2. Descriptive statistics and analysis of variance by degree

\begin{tabular}{|c|c|c|c|c|c|}
\hline & $\begin{array}{l}\text { a. Social } \\
\text { Sciences }\end{array}$ & $\begin{array}{l}\text { b. Health } \\
\text { Sciences }\end{array}$ & $\begin{array}{l}\text { c. Technical } \\
\text { Education }\end{array}$ & & \\
\hline & $(\mathrm{n}=596)$ & $(n=758)$ & $(\mathrm{n}=260)$ & $\mathrm{p}$ & $\eta 2 p$ \\
\hline Communication & $20,83 \pm 3,3^{b}$ & $21.86 \pm 2.9^{\mathrm{a}, \mathrm{c}}$ & $21,20 \pm 3,1^{b}$ & $<0,001$ & 0,023 \\
\hline Leadership & $22,23 \pm 4^{b}$ & $22,73 \pm 3,8^{\text {a }}$ & $23,29 \pm 3,4^{\mathrm{a}}$ & $<0,001$ & 0,01 \\
\hline Teamwork & $21,11 \pm 3,7^{\mathrm{b}}$ & $22,31 \pm 3,4^{\mathrm{a}}$ & $22,35 \pm 3^{\text {a }}$ & $<0,001$ & 0,031 \\
\hline Adaptation & $16,22 \pm 4,2$ & $16,42 \pm 3,9^{\mathrm{c}}$ & $17.47 \pm 4^{\mathrm{a}, \mathrm{b}}$ & $<0,001$ & 0,009 \\
\hline Initiative & $29,24 \pm 3,4^{\mathrm{b}}$ & $28.44 \pm 3.3^{\mathrm{a}, \mathrm{c}}$ & $29,53 \pm 3,4^{b}$ & $<0,001$ & 0,012 \\
\hline Problem solving & $28,41 \pm 4,4^{\mathrm{b}}$ & $29,11 \pm 4,2^{\text {a }}$ & $29,33 \pm 4,1^{\text {a }}$ & $<0,001$ & 0,01 \\
\hline Decision-making & $20,66 \pm 3,7^{\mathrm{b}}$ & $21,19 \pm 2,8^{\text {a }}$ & $21,32 \pm 2,9^{\mathrm{a}}$ & 0,001 & 0,009 \\
\hline Planning & $22,57 \pm 3,6^{b}$ & $23,37 \pm 3,4^{\mathrm{a}}$ & $23,28 \pm 3,5^{\text {a }}$ & $<0,001$ & 0,016 \\
\hline
\end{tabular}

Abbreviations. p: p-value (in bold significant differences); $\eta 2 p$ : partial eta squared. Superscript characters reflect post-hoc differences between knowledge areas: ${ }^{\mathrm{a}}$ respect to Social Sciences; ${ }^{\mathrm{b}}$ respect to Health Sciences; ${ }^{\mathrm{c}}$ respect to Technical Education

Table 3 shows the differences in the development of competencies compared by knowledge area and gender. As regards the interaction between the degree and gender, significant differences were observed in the Communication, Leadership, Problem Solving and Planning competencies $(\mathrm{p}<0.05)$, with the magnitude of the effect being small $(\eta 2 \mathrm{p}<0.01)$.

Comparison of competencies between degrees segregated by gender revealed that women studying Technical Education had higher Leadership competence compared to students in Health Sciences and Social Sciences. In addition, students in Technical degrees also had higher competence in Problem Solving and Communication than students in Social Sciences. In terms of men, the Health Science students showed greater competence in Planning, Problem Solving, Leadership and Communication than the Social Science students and better competence in Communication than the Technical Science students. Technical students were more competent in Planning than 
Social Science students.

Table 3. Development of comparative competencies by area of knowledge and gender

\begin{tabular}{|c|c|c|c|c|c|c|c|c|}
\hline & \multicolumn{2}{|c|}{ a. Social Sciences } & \multicolumn{2}{|c|}{ b. Health Sciences } & \multicolumn{2}{|c|}{ c. Technical Education } & \multirow[t]{2}{*}{$\mathrm{p}$} & \multirow[t]{2}{*}{$\eta^{2} \mathrm{p}$} \\
\hline & $\begin{array}{l}\text { 1. Male } \\
(n=270)\end{array}$ & $\begin{array}{l}\text { 2. Female } \\
(n=326)\end{array}$ & $\begin{array}{l}\text { 1. Male } \\
(n=299)\end{array}$ & $\begin{array}{l}\text { 2. Female } \\
(n=459)\end{array}$ & $\begin{array}{l}\text { 1. Male } \\
(n=195)\end{array}$ & $\begin{array}{l}\text { 2. Female } \\
(n=65)\end{array}$ & & \\
\hline Communication & $20,8 \pm 3,4^{b}$ & $20,9 \pm 3,3^{b, c}$ & $22 \pm 2,9^{a, c}$ & $21,8 \pm 3^{a}$ & $20,9 \pm 3,1^{b, 2}$ & $22,1 \pm 3^{\mathrm{a}, 1}$ & 0,026 & 0,005 \\
\hline Leadership & $22,5 \pm 4^{b}$ & $22 \pm 4^{\mathrm{c}}$ & $23,9 \pm 3.4 \mathrm{a}, 2$ & $22 \pm 3,9^{c, 1}$ & $23,2 \pm 3,4$ & $23,5 \pm 3,5^{\mathrm{a}, \mathrm{b}}$ & $<0,001$ & 0,01 \\
\hline Teamwork & $20,7 \pm 4,1$ & $21,5 \pm 3,2$ & $22,1 \pm 3,3$ & $22,4 \pm 3,5$ & $22,1 \pm 3$ & $23,1 \pm 2,9$ & 0,233 & 0,002 \\
\hline Adaptation & $16,2 \pm 3,8$ & $16,2 \pm 4,5$ & $16,9 \pm 3,6$ & $16,1 \pm 4,1$ & $17,4 \pm 4$ & $17,6 \pm 4,1$ & 0,094 & 0,003 \\
\hline Initiative & $29,5 \pm 3,3$ & $29 \pm 3,4$ & $29,1 \pm 3,2$ & $28 \pm 3,2$ & $29,7 \pm 3,3$ & $29,2 \pm 3,9$ & 0,169 & 0,002 \\
\hline Problem solving & $28,6 \pm 4,5^{b}$ & $28.3 \pm 4.3^{c}$ & $30 \pm 3.9^{a, 2}$ & $28,5 \pm 4,2^{1}$ & $29,2 \pm 4,1$ & $29,7 \pm 4.3^{\text {a }}$ & $\mathbf{0 , 0 0 4}$ & 0,007 \\
\hline Decision-making & $20,9 \pm 3,3$ & $20,4 \pm 3$ & $21,7 \pm 2,7$ & $20,9 \pm 2,9$ & $21,4 \pm 2,9$ & $21,2 \pm 2,9$ & 0,25 & 0,002 \\
\hline Planning & $21,4 \pm 3,7^{\mathrm{b}, \mathrm{c}, 2}$ & $23,5 \pm 3,4^{1}$ & $23 \pm 3.3^{\mathrm{a}, 2}$ & $23,6 \pm 3,4^{1}$ & $22,9 \pm 3.5^{\mathrm{a}, 2}$ & $24,4 \pm 3,2^{1}$ & $<0,001$ & 0,01 \\
\hline
\end{tabular}

Abbreviations. p: p-value (in bold significant differences); $\eta^{2}$ p: partial eta squared.

Superscript characters reflect post-hoc differences between knowledge areas in the same gender: ${ }^{\text {a }}$ with respect to Social Sciences; ${ }^{\mathrm{b}}$ with respect to Health Sciences; ${ }^{\mathrm{c}}$ with respect to Technical Education

Superscript numbers reflect post-hoc differences between gender in the same knowledge area: ${ }^{1}$ with respect to males; ${ }^{2}$ with respect to females.

In Communication it is observed that men who study Health Sciences are more competent than those who study Social Sciences and Technical degrees. In addition, women studying Health or Technical degrees are more competent than those studying Social Sciences. Finally, women in Technical degrees perceive greater competence in Communication than men in the same area of knowledge.

In Leadership, men who study Health perceive greater competence than those who study Social Sciences. Women studying Technical degrees have greater leadership skills than those studying Health or Social Sciences. Finally, men who study Health perceive more leadership competence than women who study the same area of knowledge.

In problem solving, men who study Health perceive more competence than Social Science students, and women who study Technical degrees perceive more competence than Social Science students. Finally, men studying Health perceive greater competence than women studying the same subject area.

In Planning, men who study Health or Technical degrees are more competent than those who study Social Sciences. In addition, women are more competent in Planning in all three subject areas than men. Figure 1 below shows the graph of differences between gender and degree programs in each competence.

\section{Discussion}

The importance of the development of transversal skills for employability has aroused interest among researchers and several studies have been carried out in this regard. However, the relationship between gender and academic degree, and the interaction between both factors in the development of competencies of students who have already completed their training cycle and are about to graduate, has not been addressed so far.

The large and significant sample that has participated in this study has allowed us to make a multivariate approach to the interactions, in which we have been able to analyze gender, degree and the interaction between both variables. In addition, information has been collected from a considerable number of both public and private institutions, which has contributed to the representativeness of the sample. On the other hand, the measurement of competencies has been carried out by means of a standardized questionnaire available on the market. As far as we know, there is no previous work which has carried out these measurements with these tools, which provides validity and reliability to the study.

Through this research we have found that there are differences in the level of development of all the transversal competencies studied, pointing to the influence of gender and the degree on the overall development of transversal competencies, which explain $6.5 \%$ and $3.7 \%$ respectively.

In relation to gender, the differences between women and men are low or moderate, although they occur in a large 
number of skills. Men perform better in more competencies, which would be in line with other authors such as Ferreras, Hernández and Serradel (2020). In our study, women show a significantly higher level of development than men in Planning and Teamwork. These results would corroborate those obtained by Garaigordobil and Durá (2006), García, Redondo, Santiago, López, and Cruz (2015) in Teamwork, García-Valcárcel and Arras Vota, (2010) in the capacity of Planning and organization. However, men perform significantly better in Leadership, Initiative and Decision-making, which would contradict the studies by Santana, Feliciano and Jiménez (2012) in Initiative.

These differences between men and women may be related to typical male and female stereotypes and typically attributed behaviors. In relation to the gender gap between STEAM degrees, an analysis of professional competencies in engineering studies, Tazo, Boyano, Fernandez-Gámiz and Calleja-Ochoa (2020) identified a relationship between the masculinization of transversal competencies in the degree. In this sense, socio-labor gender stereotypes and biased professional roles could be influencing the professional competencies developed by women and men.

On the other hand, a low self-concept in women could be behind these differences. Trianes, Cardelle-Elawar, Blanca and Muñoz, (2003) already pointed out that gender is a source of differences in the self-evaluation of social skills, with gender and self-concept being connected in various ways (Koestner and Aube, 1995). This is one of the most important variables within the motivational field, not only because of the influence it can have on the student's attributional behavior, but also because of the incidence it has on the activation of different cognitive and self-regulation strategies in school learning (González-Pienda and Núñez, 1997).

Gender stereotypes and self-concept could be behind a certain competence gap between men and women, being variables that impact on students' competence performance from pre-university stages. Padilla, García and Suárez (2015) found significant differences in social self-concept in the adolescent stage, specifically in students in 4th year of ESO, being lower in women. These authors already pointed out "the importance of detecting gender differences in self-concept, with special interest in the adolescent stage. It is to be expected that educational and vocational choices are influenced by self-concept, so that a worse self-image in the group of girls could negatively condition their life choices" (p.512).

These findings are of great importance to higher education institutions and could change the way they design their programs. Not only do skills, attitudes, abilities and knowledge play a role in competitive performance, but it is also relevant to work on other socio-emotional skills in order to obtain the best results from students. Higher education study programs should take into account these differences when designing the curricula, integrating activities, strategies and evaluation systems that help students to obtain optimum performance at the end of their studies. However, part of the learning of transversal competencies is developed through formal and non-formal training, in close family and social environments. Therefore, we believe it is relevant to work on the development of transversal competencies from childhood, at basic levels of education, and from different development environments.

In relation to competencies by degree, the results show differences in the development of transversal competencies among students in the different branches of knowledge, along the same lines as other authors such as Ayza, Rodríguez, Dubreuil and Cebrián, (2010) and Martinez and Gonzalez (2019). The differences to the detriment of Social Sciences could be due to the configuration of the programs, with a greater load of theoretical content and less practical content than other disciplines such as engineering and health sciences. The learning of competencies requires their implementation to develop these skills. While Health degrees have programs where internships in centers with patients are early and in technical education it is common for them to carry out work autonomously throughout the training stage, students in social sciences do so late and perhaps not at all for their incorporation into the working environment.

On the other hand, there could be a certain bias among teachers when choosing activities and their relation to the competencies that the student should develop. In this line (Santiago, Redondo, Escribano and Lara, 2012) they found that collaborative work seems to be the preferred type of activity for the development of almost any of the transversal competencies and in all the disciplines analyzed, followed by document analysis and critical analysis of information sources. These differences may have to do with the ease with which the development of some of them is inferred when analyzing student deliverables or the previous preparation of the authors themselves in these competencies and their subsequent assessment.

Planning competence seems to be clearly more developed in women than in men, regardless of the degree studied. These results could indicate a better adaptation of women when they finish their studies to management skills, with planning/organization being one of the most significant (González, Pérez and Quijano, 2020). 
However, this study has its limitations. The collection of information has been based on quantitative techniques. We believe that introducing qualitative assessment tools, which are more sensitive than normative evidence, could provide relevant information that has so far not been collected. We also believe that this study could be completed by including the assessment of employers as key informants in the development of transversal competencies of graduates. Finally, it is important to extend the study to the competencies of social responsibility, ethics and gender equality, which are key in today's society. Finally, in the future this study could be extended to other international higher education centers, extending the sample to final year students from institutions other than those in Spain.

\section{Conclusion}

The main conclusions of this study are presented below:

- Gender and area of knowledge and their interaction are factors that modulate the competitive performance of university students.

- Differences in the performance of competencies between men and women could have their origin in cognitive-motivational variables, such as academic self- concept.

- Gender stereotypes would have a negative influence on competence learning, which could be generating a certain competence gap between men and women.

- The learning of transversal competencies requires that training programs are designed with a lower theoretical load and a higher practical load, regardless of the degree studied, since it requires their implementation for their optimal development.

- Women, regardless of the area of knowledge, could be more suitable for management and coordination positions at the time of graduation, where Planning is a key competence.

\section{References}

Alles, M. (2006). Desempeño por competencias: evaluación de 360.Buenos Aires: Ediciones Granica S.A.

Alonso-Martín, A. (2010). La importancia y el nivel de desarrollo de las competencias en psicología. Psicología desde el Caribe, 25, 84-107.

Arras Vota, A. M. G., Torres Gastelú, C. A., \& García-Valcárcel Muñoz-Repiso, A. (2011). Competencias en Tecnologías de Información y Comunicación (TIC) de los estudiantes universitarios. Revista Latina de Comunicación Social, 66, 1-26. https://doi.org/10.4185/rlcs-66-2011-927-130-152

Arribas, D., \& Brand, J. P. (2015). CompeTEA. TEA Ediciones.

Avendaño, C. A., Gutiérrez, K. A., Salgado, C. F., \& Alonso-Dos-Santos, M. (2016). Rendimiento Académico en Estudiantes de Ingeniería Comercial: Modelo por Competencias y Factores de Influencia. Formación Universitaria, 9(3), 2016, 3-10. https://doi.org/10.4067/s0718-50062016000300002

Ayza, M. R., Rodríguez M. F., Dubreuil G. E., \& Cebrián M. D. M. (2010). La evaluación de competencias transversales en la materia trabajos fin de grado. Un estudio preliminar sobre la necesidad y oportunidad de establecer medios e instrumentos por ramas de conocimiento. REDU. Revista de docencia universitaria, 8(1), 74. DOI: https://doi.org/10.4995/redu.2010.6218

Barrientos, C., Silva, P., \& Antúnez, S. (2016). Competencias directivas para promover la participación: familias en las escuelas básicas. Educación, 2(49), 45-62. https://doi.org/10.18800/educacion.201602.003

Boyatzis, R. E. (1982). The Competent Manager. New York: John Wiley \& Sons.

Bunk, G. (1994). La transmisión de las competencias en la formación y perfeccionamiento profesionales de la RFA. Revista Europea de formación profesional, 1-94. Available on https://dialnet.unirioja.es/servlet/articulo?codigo $=131116$

Casanova, M. A. (2016). El diseño curricular como factor de calidad educativa. REICE. Revista Iberoamericana sobre Calidad, Eficacia y Cambio en Educación, 10(4), 7-20. https://doi.org/10.15366/reice2016.14.3

Castellanos, A., Sánchez, C., \& Calderero, J. F. (2017). Nuevos modelos tecnopedagógicos. Competencia digital de los alumnos universitarios. Revista Electrónica de Investigación Educativa, 19(1), 1-9. https://doi.org/10.24320/redie.2017.19.1.1148

Castro, J. M. C., \& Martini, H. A. (2014). Potencia estadística y cálculo del tamaño del efecto en G* Power: complementos a las pruebas de significación estadística y su aplicación en psicología. Salud \& sociedad, 5(2), 


\section{0-244. https://doi.org/10.22199/S07187475.2014.0002.00006}

Consejo General de Colegios Oficiales de Psicólogos. (2015). Evaluación del Test CompeTEA. Available on https://www.cop.es/uploads/PDF/2013/CompeTEA.pdf

Clares, P. M., \& Morga, N. G. (2019). El dominio de competencias transversales en Educación Superior en diferentes contextos formativos. Educação e Pesquisa, 45(1). https://doi.org/10.1590/s1678-4634201945188436

Corominas, E., Tesouro, M., Capell, D., Teixeidó, J., Pèlach, J., \& Cortada, R. (2006). Percepciones del profesorado ante la incorporación de las competencias genéricas en la formación universitaria. Revista de educación, 341, 301-336. Available on http://hdl.handle.net/10256/9861

Díaz Barriga, A. (2005). El enfoque de competencias en la educación. ¿Una alternativa o un disfraz de cambio? Perfiles educativos, 8(11), 7-36. Available on https://www.redalyc.org/articulo.oa?id=13211102

Echeverría, B. (2002). Gestión de la competencia de acción profesional. Revista de Investigación Educactiva, 20(1), 7-42. Available on https://revistas.um.es/rie/article/view/97411

Escobar Valencia, M. (2005). Las competencias laborales: ¿La estrategia laboral para la competitividad de las organizaciones? Estudios Gerenciales, 96, 31-55. Available on http://www.redalyc.org

Declaración de Bolonia. (1999). El espacio europeo de la enseñanza superior. Declaración conjunta de los ministros europeos de educación reunidos en Bolonia el 19 de junio de 1999. Available on https://www.uemc.es/documents/download/108

EURYDICE. (2010). Diferencias de género en los resultados educativos: medidas adoptadas y situación actual en Europa. Ministerio de Educación. Available https://www.educacionyfp.gob.es/dam/jcr:cff4fb4a-10cd-4150-8d13-ab5205a8dd1e/diferencias-de-genero-en-lo s-resultados-educativos.pdf

Everis, F. (2015). Ranking Universidad-Empresa. Encuesta a las empresas españolas sobre la empleabilidad de los titulados superiores. Available on https://www.upv.es/noticias-upv/documentos/ranking_everis_2015.pdf

Ferrari, G., Santiago, G., Redondo S., \& Sánchez, A. (2015). Desarrollo de competencias transversales en estudiantes de postgrado de la Universidad Europea a través de un Small Private Online Course. XII Jornadas Internacionales de Innovación Universitaria, 497-505. https://doi.org/10.35985/9789585522725.4

Fragoso-Luzuriaga, R. (2015). Inteligencia emocional y competencias emocionales en educación superior $i$ un mismo concepto? Revista iberoamericana de educación superior, 6(16), 110-125. https://doi.org/10.1016/j.rides.2015.02.001

Garaigordobil, M., \& Durá, A. (2006). Relaciones de autoconcepto y la autoestima con sociabilidad, estabilidad emocional y responsabilidad en adolescentes de 14 a 17 años. Análisis y modificación de conducta, 32(141), 37-64. https://doi.org/10.33776/amc.v32i141.2132

García, O., Redondo, S., Santiago, G., López, F., \& Cruz, A. (2015). Perfil competencial de los estudiantes de últimos cursos de grado en las universidades de la Comunidad de Madrid: Diferencias en función del género y la edad. Higher Learning Research Communications, 5(2), 57-66. https://doi.org/10.18870/hlrc.v5i2.225

Garrido, M. C., Santiago, G., Gómez-Márquez, M., Poggio, L., \& Gómez, S. (2019). Impacto de los recursos digitales en el aprendizaje y desarrollo de la competencia Análisis y Síntesis. Educación Médica, 20(2), 74-78. https://doi.org/10.1016/j.edumed.2018.02.011

Gil-Flores, J. (2007). La evaluación de competencias laborales. Educación, 11(10), 83-106. https://doi.org/10.5944/educxx1.1.10.298

González, D. G., Pérez, J. E. C., \& Quijano, M. M. (2020). La planificación/organización, una competencia directiva necesaria para los cuadros de dirección de las instituciones universitarias. Estrategia y Gestión Universitaria, 8(2), 92-117.

González-Pienda García, J. A., \& Núñez , J. C. (1997). Determinantes personales del aprendizaje y rendimiento académico. Instrucción, aprendizaje y dificultades.

Hernández-March, J., Del Peso, M. M., \& Leguey, S. (2009). Graduates' skills and higher education: The employers' perspective. Tertiary education and management, 15(1), 1-16. https://doi.org/10.1080/13583880802699978

I Jubany, A. S., \& Jurnet, I. A. (2016). Entrenamiento de las habilidades de oratoria en estudiantes universitarios mediante la exposición a ambientes virtuales. In EDUNOVATIC 2016-I Congreso Virtual internacional de 
Educación, Innovación y TIC. 220-222. Available on https://dialnet.unirioja.es/servlet/articulo?codigo=5792773

Informe de Competencias Profesionales en Preuniversitarios y Universitarios de Iberoamérica. (2013). Fundación Telefónica Universia. Available on http://comunidad.psyed.edu.es/file/view/14014/informe-de-competencias-profesionales-en-preuniversitarios-yuniversitarios-de-iberoamerica

Lévy-Leboyer, C. (2000). Gestión de las competencias. Barcelona: Ediciones Gestión.

Lim, K., Eom, S., Kim, D., \& Oh, M. (2020). Understanding Gender Differences in Students' Perceptions of Competency Certification for Enhancing Sustainability in Higher Education. Sustainability, 12(19), 8233. https://doi.org/10.3390/su12198233

López C., Benedito, V., \& León, M. J. (2016). El Enfoque de Competencias en la Formación Universitaria y su Impacto en la Evaluación. La Perspectiva de un Grupo de Profesionales Expertos en Pedagogía. Formación Universitaria, 12(4). https://doi.org/10.4067/s0718-50062016000400003

Martínez-Flores, F. G., \& Delgado-Sánchez, U. (2017). Estilos de aprendizaje, elección de carrera y perfil curricular en estudiantes de Comunicación Humana. Revista Digital de Investigación en Docencia Universitaria, 11(2), 274-287. https://doi.org/10.19083/ridu.11.526

McClelland, D. C. (1973). Testing for competence rather than for "intelligence". American Psychologist, $28,1-18$. https://doi.org/10.1037/h0034092

Mendo Lázaro, S., León del Barco B., Felipe Castaño E., y Polo del Río M.I. (2016). Entrenamiento en habilidades sociales en el contexto universitario: Efecto sobre las habilidades sociales para trabajar en equipos y la ansiedad social. Behavioral Psychology/Psicologia Conductual, 24(3), 423-438. Available on https://www.researchgate.net/publication/316951807_Entrenamiento_en_habilidades_sociales_en_el_contexto_ universitario_Efecto_sobre_las_habilidades_sociales_para_trabajar_en_equipos_y_la_ansiedad_social

Michavila, F., Martínez, J. M., Martín-González, M., García-Peñalvo, F. J., \& Cruz-Benito, J. (2016). Barómetro de Empleabilidad y Empleo de los Universitarios en España (Primer informe de resultados). Madrid: Observatorio de Empleabilidad y Empleo Universitarios. Available on https://gredos.usal.es/handle/10366/127374

Miller George, E. (1990). The assessment of clinical skills/competence/performance. Academic Medicine, 9, 63-67. https://doi.org/10.1097/00001888-199009000-00045

Montero, I. L., \& León, O. (2002). Clasificación y descripción de las metodologías de investigación en Psicología. Revista Internacional de Psicología Clínica y de la Salud, 2(3), 503-508. Available on http://www.aepc.es/ijchp/articulos_pdf/ijchp-53.pdf

Morales, S., \& Morales, O. (2020). Por qué hay pocas mujeres científicas? Una revisión de literatura sobre la brecha de género en carreras STEM. aDResearch: Revista Internacional de Investigación en Comunicación, (22), 118-133. https://doi.org/10.7263/adresic-022-06

Morgado, E. M., Peñalvo, F. G., Ortuño, R. C., \& Hidalgo, C. A. (2015). Desarrollo de competencias a través de objetos de aprendizaje. Revista de Educación a Distancia, (36). Available on http://hdl.handle.net/10366/121505

Observatorio de innovación para el empleo. (2014). Informe OIE sobre jóvenes y mercado laboral. Observatorio de $\begin{array}{lllll}\text { Innovación } & \text { para } & \text { el } & \text { Empleo. } & \text { Recovered }\end{array}$ http://www.injuve.es/noticia/informe-oie-sobre-jovenes-y-mercado-laboral

Oficina Internacional del Trabajo. (1997). Formación basada en competencia laboral:situación actual y perspectivas. https://www.oitcinterfor.org/sites/default/files/file_publicacion/libmex.pdf

Padilla, M. T., García, M. S., \& Suárez, M. (2010). Diferencias de género en el autoconcepto general y académico de estudiantes de $4^{\circ}$ de ESO. Revista de Educación, 352, 495-515. https://doi.org/10.6018/rie.334301

Peñalva-Vélez, A., López-Goñi, J. J., \& García-Manso, M. I. (2016). El desarrollo de las competencias emocionales en alumnado de secundaria: perfiles diferenciales en función del sexo. Educatio Siglo XXI, 34(1), 223-242. https://doi.org/10.6018/j/253301

Rodríguez, S., Fita, E., \& Torrado, M. (2004, agosto,). El rendimiento académico en la transición secundaria-universidad. Revista de Educación, 334, 391-414. Recovered from 
https://dialnet.unirioja.es/servlet/ejemplar?codigo=96318\&info=open_link_ejemplar

Ruiz-Gutiérrez, J. M., \& Santana-Vega, L. E. (2018). Elección de carrera y género. Revista Electrónica de Investigación y Docencia (REID), (19), 7-20. https://doi.org/10.17561/reid.v0i19.3470

Rusillo, M. T. C., \& Arias, P. F. C. (2004). Diferencias de género en la motivación académica de los alumnos de Educación Secundaria Obligatoria. Electronic journal of research in educational psychology, 2(1), 97-112. https://doi.org/10.25115/ejrep.3.125

Santana, L. E., Feliciano, L., \& Jiménez, A. B. (2012). Toma de decisiones y género en el Bachillerato. Revista de Educación, 359, 357-387. DOI: 10.4438/1988-592X-RE-2011-359-098

Samuel, O. M., \& Mokoaleli, I. (2017). Analysis of gender and leadership role competencies, perceptions and stereotypes in an organisational context. South African Journal of Business Management, 48(2), 55-66. DOI: https://doi.org/10.4102/sajbm.v48i2.28

Santiago, G., Escribano, J. J., Redondo, S., \& Lara P. J. (2012) Desarrollo de competencias a través de actividades: estudio del caso de materias on-line en la UEM. III Congreso Iberoamericano sobre Calidad y Accesibilidad de la Formación Virtual (214-221). https://doi.org/10.15332/dt.inv.2020.01555

Santiago, G., Redondo, S., \& García, O. (2018). Evaluation of Academic Competencies through Standardized Instruments: A Comparison of CompeUEM, LPA-Q, and ESCI-U. Higher Learning Research Communications, 8(1). https://doi.org/10.18870/hlrc.v8i1.395

Santos, M. (2005). La Universidad ante el proceso de convergencia europea: un desafío de calidad para la Unión. Revista Española de Pedagogía, (230), 5-16. https://doi.org/10.7179/psri_2007.14.02

Spencer, L., \& Spencer, S. (1993). Competence at work, models for superior performance. Neva York: John Wiley \& Sons. Recovered from https://dialnet.unirioja.es/servlet/articulo?codigo=7545349\&orden=0\&info=link

Tazo, M. I., Boyano, A., Fernandez-Gámiz, U., \& Calleja-Ochoa, A. (2020). The Gender Perspective of Professional Competencies in Industrial Engineering Studies. Sustainability, 12(7), 2945. https://doi.org/10.3390/su12072945

Tobón, S. (2006). Aspectos básicos de la formación basada en competencias. Talca: Proyecto Mesesup.

Tobón, S. (2008). La formación Basa en competencias en la educación superior. Guadalajara: grupo Cife.

Van-der Hofstadt Roman, C., \& Gras, J. M. G. (2013). Competencias y habilidades profesionales para universitarios. Ediciones Díaz de Santos: Madrid. Recovered from http://www.editdiazdesantos.com/wwwdat/pdf/9788479787967.pdf

Von Elm, E., Altman, D. G., Egger, M., Pocock, S. J., Gøtzsche, P. C., \& Vandenbroucke, J. P. (2008). Declaración de la Iniciativa STROBE (Strengthening the Reporting of Observational studies in Epidemiology): directrices para la comunicación de estudios observacionales. Gaceta Sanitaria, 22(2), 144-150. https://doi.org/10.1157/13119325

Zaragoza, I. D. (2008). Competencias Genéricas y transversales de los titulados universitarios. Universidad de Zaragoza. $\quad$ Recovered from https://ice.unizar.es/sites/ice.unizar.es/files/users/leteo/publicaciones/col._documentos_08.pdf

\section{Copyrights}

Copyright for this article is retained by the author(s), with first publication rights granted to the journal.

This is an open-access article distributed under the terms and conditions of the Creative Commons Attribution license (http://creativecommons.org/licenses/by/4.0/). 